\title{
Comparison of the effects of SGLT 2 inhibitors and sulfonylurea on electrocardiographic parameters
}

\section{SGLT 2 inhibitörleri ve sülfonilürenin elektrokardiyografik parametreler üzerindeki etkilerinin karşılaştırılması}

\author{
Onur Akhan ${ }^{1}$, Ebru Şahim ${ }^{1}$, Ramazan Aslan ${ }^{1}$, Ahmet Aktaş ${ }^{2}$
}

Department of Cardiology, Bilecik Training and Research Hospital, Bilecik, Turkey

${ }^{2}$ Department of Internal Medicine, Sivas Cumhuriyet University Faculty of Medicine Sivas, Turkey

Corresponding author: Onur Akhan, MD, Department of Cardiology, Bilecik Training and Research Hospital, Bilecik, Turkey

E-mail: akhanonur@gmail.com

Received/Accepted: February 12, 2021 / March 28, 2021

Conflict of interest: There is not a conflict of interest.

\section{SUMMARY}

Objective: Tp-e, QT, and Tp-e / QT are parameters showing ventricular repolarization. The increase in these parameters causes an increase in cardiovascular mortality, mostly due to malignant arrhythmias. Our study aimed to compare the long-term changes in electrocardiographic parameters in patients with uncontrolled diabetes despite using metformin, with the addition of SGLT 2 inhibitor or sulfonylurea (SU) to the treatment.

Method: This retrospective study was enrolled in 133 type 2 DM patients with uncontrolled diabetes who applied to the internal medicine outpatient clinic, using single oral antidiabetic agents. The patients were divided into two groups as SU and SGLT 2 inhibitor additive. SU was added to the treatment of 69 patients, and SGLT 2 inhibitor was added to 64 patients. 12lead superficial ECG records of participants who received combined therapy for at least six months were analyzed and compared. RR distance, QT interval, and Tp-e intervals were measured on the ECG. QTc was calculated using Bazzet's formula. (QT/ ل RR). Tp-e / QT and Tp-e / QTc ratios were calculated.

Results: Seventy-eight $(58.6 \%)$ of the participants were female, and 55 (41.4) were male. The age and gender distribution of both groups were similar. The group to which SGLT 2 inhibitor was added, Tp-e, QT, and QTc distances were significantly lower than the SU group ( $<<0.001$ for each). Also, the Tp-e / QT and Tp-e / QTc ratios were significantly greater in the SU group $(0.210 \pm 0.029$ vs $0.190 \pm 0.03 ; \mathrm{p}<0.001$ and $0.201 \pm 0.051$ vs $0.184 \pm 0.032 ; \mathrm{p}=0.022$ respectively).

Conclusions: In our study, we showed that the addition of SGLT2 inhibitors to monotherapy in people with diabetes with poor glycemic control has a positive effect on ECG parameters, which are indicators of repolarization, compared to other oral antidiabetics.

Keywords: SGLT 2 inhibitors, sulfonylurea, ventricular repolarization, Type 2 diabetes mellitus

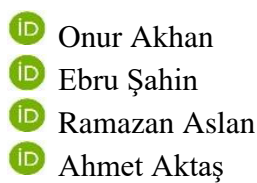

ORCID IDs of the authors: O.A. 0000-0003-4440-9599 E.S. 0000-0002-2231-126X R.A. 0000-0002-1255-7880 A.A. 0000-0001-9464-0700 
Amaç: Tp-e, QT ve Tp-e / QT ventriküler repolarizasyonu gösteren parametrelerdir. Bu parametrelerdeki artış, çoğunlukla malign aritmilere bağlı olarak kardiyovasküler mortalitede artışa neden olur. Çalışmamız, metformin kullanımına rağmen kontrolsüz diabetes mellituslu hastalarda tedaviye SGLT 2 inhibitörü veya sülfonilüre (SU) ilave edilmesiyle elektrokardiyografik parametrelerdeki uzun süreli değişiklikleri karşılaştırmayı amaçladı.

Yöntem: Bu retrospektif çalışma, iç hastalıkları polikliniğine başvuran tek oral antidiyabetik ajan kullanan, kontrolsüz diyabetli 133 tip 2 DM hastası üzerinde yapıldı. Hastalar tedaviye SU ve SGLT 2 inhibitörü eklenenler olarak iki gruba ayrıldı. 69 hastanın tedavisine SU, 64 hastaya SGLT 2 inhibitörü eklendi. En az altı ay boyunca kombine tedavi gören katılımcıların 12 derivasyonlu yüzeysel EKG kayıtları analiz edildi ve karşılaştırıldı. EKG'de RR mesafesi, QT aralığı ve Tp-e aralıkları ölçüldü. QTc, Bazzet formülü kullanılarak hesaplandı. (QT / V RR). Tp-e / QT ve Tp-e / QTc oranları hesaplandi.

Bulgular: Katılımcıların 78'i (\% 58,6) kadın, 55'i $(41,4)$ erkekti. Her iki grubun yaş ve cinsiyet dağılımı benzerdi. SGLT 2 inhibitörü eklenen grup, Tp-e, QT ve QTc mesafeleri SU grubuna göre anlamlı olarak daha düşüktü (her biri için p $<0.001$ ). Ayrıca Tp-e / QT ve Tp-e / QTc oranları SU grubunda anlamlı olarak daha yüksekti (sırasıyla $0,210 \pm 0,029$ 'a karș1 $0,190 \pm 0,03 ; p<0,001$ ve $0,201 \pm 0,051$ 'e karș1 $0,184 \pm 0,032 ; p=0,022)$.

Sonuç: Çalışmamızda glisemik kontrolü zayıf diyabetli kişilerde monoterapiye SGLT2 inhibitörlerinin eklenmesinin repolarizasyon göstergesi olan EKG parametreleri üzerinde diğer oral antidiyabetiklere göre olumlu etkisi olduğunu gösterdik.

Anahtar sözcükler: SGLT 2 inhibitörleri, sülfonilüre, ventriküler repolarizasyon, Tip 2 diyabetes mellitus.

\section{INTRODUCTION}

Diabetes Mellitus (DM) is an important health problem with an increasing prevalence worldwide. Although recently developed treatment methods are promising, it is a common cause of mortality and morbidity, primarily due to the complications it causes ${ }^{1}$. Cardiac complications have an essential place among these. Empagliflozin and dapagliflozin are Sodium-Glucose Co-transporter (SGLT 2) inhibitor that acts independently of insulin and decreases blood glucose levels by increasing glucose excretion from urine ${ }^{2}$. SGLT2 inhibitors can be used alone or in combination with other antidiabetics. Recently, its positive cardiac effects have been proven by large-scale studies. It has been reported that it decreases hospital stay and mortality, especially in heart failure with reduced ejection fraction and diastolic dysfunction ${ }^{3}$. However, its effects on ventricular arrhythmia are not clearly known. Clinical studies have reported that the Tp-e interval and Tp-e / QT ratio are helpful but straightforward parameters for predicting increased ventricular arrhythmias and cardiovascular events. It is more effective in showing ventricular repolarization because it is not affected by heart rate like QT and QT dispersion (QTd) ${ }^{4}$. Many studies have shown that prolonged TP-e interval is associated with increased cardiac mortality ${ }^{5-9}$.

Our study examined the effect of adding empagliflozin or dapagliflozin to treatment on $\mathrm{Tp}$ e and Tp-e/QT, which are indicators of ventricular repolarization, in patients receiving monotherapy and with unregulated type $2 \mathrm{DM}$.

\section{MATERIAL AND METHODS}

One hundred thirty-three type 2 DM patients who applied to endocrinology and internal medicine outpatient clinics and had insufficient glycemic control were included in the study. These patients were switched from monotherapy to combination therapy with dual oral agents due to poor glycemic control. The patients were divided into two groups. The first group was the patients in whom sulfonylurea (SU) was added to the monotherapy, and the second group was the patients who had empagliflozin or dapagliflozin added. SU was added to 69 patients, and empagliflozin was added to 64 patients. Medical anamnesis of all patients participating in the study were taken, and a complete physical examination was performed. Drug use histories were questioned. Anthropometric measurements were taken and recorded. Electrocardiographic (ECG) records of the patients after combination therapy for a minimum of six months were reviewed.

12-lead ECG recording $(50 \mathrm{~mm} / \mathrm{s}, 10 \mathrm{~mm} / \mathrm{mV}$ ) was obtained using Nihon Kohden (Tokyo, Japan) brand ECG device. ECG papers were scanned and transferred to digital media, and measurements were made manually by magnifying 300 times in a computer environment. QT and Tp-e intervals and QRS duration were calculated. Corrected QT (cQT) was computed using Bazzet's formula (QT / $\sqrt{ }$ RR interval).

Those with known coronary artery disease, systolic heart failure, chronic renal failure, endocrine disorders, active infection, radiotherapy and chemotherapy treatment, those with left bundle branch block on ECG, atrial fibrillation, electrolyte disorder that may cause ECG changes (hypercalcemia, hypokalemia hypomagnesemia, 
etc.), those with a history of cardioverter defibrillator and pacemaker implantation, antiarrhythmic drug use, patients using drugs that can change the QT interval (antidepressants, neuroleptics, hydroxychloroquine, etc.) were excluded from the study.

\section{Statistical Analysis}

Statistical Package for the Social Sciences (SPSS) software (version 22.0; SPSS Inc., Chicago, IL, USA) was used to analyze the data. Categorical variables were expressed as percentage $(\%)$ and frequency. Continuous variables were expressed as mean \pm standard deviation. Kolmogorov-Smirnov and Shapiro-Wilk tests were used for the normality test of the data. A comparison between groups was made using the Mann-Whitney U- or t-test according to data distribution. The Chi-square test was used to evaluate the differences of categorical variables between groups. P-value $<0.05$ was considered significant.

\section{RESULTS}

The study group's mean age was $65.52 \pm 13.72$ years (78 female / 55 male). There was no significant difference in age and gender between the groups (66.11. \pm 10.58 vs. $65.09 \pm 12.16$, respectively, $\mathrm{p}=0.607$ ). There was no statistically significant difference between the groups regarding the number of hypertensive and hyperlipidemic patients. Table 1 shows the demographic and anthropometric measurements of the patients.

Table 1: Comparison of demographic and anthropometric measurements of the groups

\begin{tabular}{|l|l|l|l|}
\hline Parameters & $\begin{array}{l}\text { SGLT-2 inhibitor } \\
\text { added group (64) } \\
\text { (Mean } \pm \text { SD) }\end{array}$ & $\begin{array}{l}\text { Sulfonylurea added } \\
\text { group (69) } \\
\text { (Mean } \pm \text { SD) }\end{array}$ & p-value \\
\hline Age (years) & $66.11 \pm 10.58$ & $65.09 \pm 12.16$ & 0.607 \\
\hline Gender (female /male) & $38 / 26$ & $40 / 29$ & \\
\hline HT, n (\%) & $21(32.8 \%)$ & $19(27.5 \%)$ & 0.236 \\
\hline HL, n (\%) & $25(\% 39.1)$ & $29(\% 42.1)$ & 0.561 \\
\hline Smokers, n (\%) & $14(\% 21.8)$ & $16(\% 23.2)$ & 0.347 \\
\hline Duration of diabetes, years & $7.4 \pm 3.1$ & $7,8 \pm 3.5$ & 0.217 \\
\hline Body mass index $\left(\mathrm{kg} / \mathrm{m}^{2}\right)$ & $30.49 \pm 3.4$ & $29.3 \pm 4.6$ & 0.630 \\
\hline Systolic BP $(\mathrm{mmHg})$ & $130.6 \pm 11.3$ & $132.2 \pm 10.2$ & 0.725 \\
\hline Diastolic BP $(\mathrm{mmHg})$ & $81.6 \pm 5.7$ & $81.5 \pm 6.1$ & 0.843 \\
\hline LVEF $(\%)$ & $61.8 \pm 3.2$ & $62.3 \pm 4.1$ & 0.539 \\
\hline
\end{tabular}

HT: Hypertension, HL: Hyperlipidemia, BP: blood pressure, LVEF: Left ventricular ejection fraction

When biochemical parameters were compared, fasting blood glucose levels and $\mathrm{HbA1c}$ were slightly lower in the SGLT 2 inhibitor group. However, this difference had no statistical significance $(128.2 \pm 33.4$ vs $132.8 \pm 29.2 ; \mathrm{p}=$ 0.394 and $6.9 \pm 1.4$ vs $7.1 \pm 1,9 ; \mathrm{p}=0.324)$. There was no significant difference between both groups in terms of other parameters (Table 2). 
Table 2: Comparison of laboratory findings

\begin{tabular}{|l|l|l|l|}
\hline Parameters & $\begin{array}{l}\text { SGLT-2 inhibitor } \\
\text { added group (64) } \\
\text { (Mean } \pm \text { SD) }\end{array}$ & $\begin{array}{l}\text { Sulfonylurea added } \\
\text { group (69) } \\
\text { (Mean } \pm \text { SD) }\end{array}$ & p- value \\
\hline FPG (mg/dL) & $128.2 \pm 33.4$ & $132.8 \pm 29.2$ & 0.394 \\
\hline HbA1c (\%) & $6.9 \pm 1.4$ & $7.1 \pm 1,9$ & 0.324 \\
\hline Creatinine (mg/dL) & $0.86 \pm 0.22$ & $0.87 \pm 0.21$ & 0.866 \\
\hline Uric asid & $5.6 \pm 2.9$ & $5.8 \pm 3.0$ & 0.124 \\
\hline Na (mEq/L) & $137.5 \pm 6.1$ & $137.1 \pm 4.5$ & 0.692 \\
\hline K (mEq/L) & $4.6 \pm 0.6$ & $4.5 \pm 0.8$ & 0.217 \\
\hline Ca $(\mathbf{m g} / \mathbf{d L})$ & $9.5 \pm 0.7$ & $9.6 \pm 0.6$ & 0.506 \\
\hline Total CHL & $222.4 \pm 49.3$ & $218.4 \pm 38.3$ & 0.468 \\
\hline HDL-C (mg/dL) & $44.5 \pm 6.1$ & $46.5 \pm 5.6$ & 0.648 \\
\hline LDL-C (mg/dL) & $133.4 \pm 38.5$ & $132.2 \pm 35.1$ & 0.834 \\
\hline Triglyceride (mg/dL) & $181.4 \pm 71.5$ & $174.7 \pm 19.9$ & 0.591 \\
\hline AST, IU/L & $29.3 \pm 14.4$ & $32.1 \pm 13.2$ & 0.212 \\
\hline ALT, IU/L & $28.3 \pm 12.1$ & $27.3 \pm 10.6$ & 0.654 \\
\hline
\end{tabular}

FBG: Fasting plasma glucose, Na: Sodium, K: Potassium, Ca: Calcium, CHL: cholesterol, HDL: High-density lipoprotein, LDL: Low-density lipoprotein, AST: aspartate aminotransferase, ALT: alanine aminotransferase

After six months of follow-up, there was a significant decrease in Tp-e interval in patients using empagliflozin or dapagliflozin as an add-on to metformin compared to SU $(72.52 \pm 10.93 \mathrm{~ms}$ vs. $83.65 \pm 11.21 \mathrm{~ms}, \mathrm{p}<0.001)$. When the QT and QTc intervals were compared, there was a significant difference between the two groups $(383.13 \pm 31.17$ vs $398.46 \pm 25.62$ and $398.19 \pm$
46.92 vs 439. $08 \pm 63.96 ; \mathrm{p}<0.001$ for each). Also, the Tp-e / QT and Tp-e / QTc ratios were significantly lower in the empagliflozin group compared to the SU group $(0.190 \pm 0.030$ vs 0.210 $\pm 0.029 ; \mathrm{p}<0.001$ and $0.184 \pm 0.032$ vs $0.201 \pm$ $0.051 ; \mathrm{p}=0.022)$. The comparison of $\mathrm{ECG}$ parameters of the groups is shown in Table 3.

Table 3: Electrocardiographic findings between groups

\begin{tabular}{|l|l|l|l|}
\hline Parameters & $\begin{array}{l}\text { SGLT2 inhibitor } \\
\text { added group (64) } \\
\text { (Mean } \pm \text { SD) }\end{array}$ & $\begin{array}{l}\text { Sulfonylurea added } \\
\text { group (69) } \\
\text { (Mean } \pm \text { SD) }\end{array}$ & p value \\
\hline QT interval (ms) & $383.13 \pm 31.17$ & $398.46 \pm 25.62$ & $<\mathbf{0 . 0 0 1}$ \\
\hline QTc interval (ms) & $398.19 \pm 46.92$ & $439.08 \pm 63.96$ & $<\mathbf{0 . 0 0 1}$ \\
\hline Heart rate (beats/min) & $82.14 \pm 18.52$ & $77.68 \pm 13.62$ & 0.114 \\
\hline Tp-e interval (ms) & $72.52 \pm 10.93$ & $83.65 \pm 11.21$ & $<\mathbf{0 . 0 0 1}$ \\
\hline TP-e / QT & $0.190 \pm 0.030$ & $0.210 \pm 0.029$ & $<\mathbf{0 . 0 0 1}$ \\
\hline Tp-e / QTc & $0.184 \pm 0.032$ & $0.201 \pm 0.051$ & $<\mathbf{0 . 0 2 2}$ \\
\hline
\end{tabular}

Tp-e: T peak-to-end

\section{DISCUSSION}

As a result of the study, we showed that QT, QTc, Type, Tp-e / QT, and Tp-e / QTc show ventricular repolarization changed positively with the addition of SGLT 2 inhibitors to monotherapy.

Cardiovascular complications caused by DM are generally asymptomatic and silent. Therefore, early identification of complications and early initiation of necessary measures may decrease mortality. Ventricular arrhythmia also takes an important place among these complications. The risk of sudden cardiac death due to arrhythmias is higher in diabetic patients than in the average population ${ }^{10}$. The reasons for this may include silent ischemic coronary artery disease, impaired ventricular function, impaired repolarization abnormalities, and changes in cardiac autonomic 
activity. A possible cause in all these pathologies is the increased heterogeneity of ventricular repolarization. The Tp-e interval shows the transmural dispersion of ventricular repolarization ${ }^{11}$. Many studies have shown that prolonged TP-e interval is associated with increased cardiovascular mortality ${ }^{5-9}$. However, the Tp-e / QTc ratio is also a sensitive index for showing ventricular repolarization ${ }^{4}$.

In a recent large trial, empagliflozin has been shown to reduce cardiovascular mortality in type 2 DM patients at high cardiovascular risk. It has also been shown to reduce hospitalizations and improve concomitant heart failure symptoms with reduced ejection fraction ${ }^{3}$. Although the possible pathogenesis of this is not known clearly, the underlying cause is thought to be due to arterial stiffness, cardiac oxygen demand, and a decrease in volume load. In animal experiments, empagliflozin has been shown to reduce left ventricular mass and fibrosis in mice with metabolic syndrome ${ }^{12}$. In a study conducted in humans, it has been demonstrated that the 1-year use of SGLT 2 inhibitors in patients with coronary stents reduces the patency of coronary stents and the formation of new plaques ${ }^{13}$. Based on this study, we think that by providing plaque stabilization in coronary arteries, myocardial perfusion can continue well, and arrhythmia can be reduced in long rotation. In another experimental animal study, it was reported that dapagliflozin, an SGLT2 inhibitor, improves ventricular repolarization by increasing mitochondrial functions in mice with insulin resistance ${ }^{14}$.

We think that a treatment method that can improve electrocardiographic parameters such as $\mathrm{Tp}$-e, $\mathrm{Tp}$ e / QT in diabetic patients, that is, reduces the heterogeneity of ventricular repolarization, may decrease cardiovascular mortality. Our study showed that the addition of empagliflozin, an SGLT 2 inhibitor, to the treatment due to insufficient glycemic control despite taking metformin improved ECG parameters, which is an indicator of ventricular arrhythmia.

\section{LIMITATIONS}

The study's main limitation was that the number of patients was relatively small, and it was a singlecenter study. Another limitation was our analysis of two oral antidiabetic drugs in combination therapy. There is a need to investigate the benefits of SGLT2 inhibitors on arrhythmia with extensive population studies, including other antidiabetics.

\section{REFERENCES}

1. Ogurtsova K, da Rocha Fernandes JD, Huang Y, Linnenkamp U, Guariguata L, Cho NH, Cavan D, Shaw JE, Makaroff LE. IDF Diabetes Atlas: Global estimates for the prevalence of diabetes for 2015 and 2040. Diabetes Res Clin Pract. 2017 Jun;128:40-50. doi: 10.1016/j.diabres.2017.03.024.

2. Scheen AJ. Cardiovascular Effects of New Oral Glucose-Lowering Agents: DPP-4 and SGLT-2 Inhibitors. Circ Res. 2018 May 11;122(10):1439-1459. doi: 10.1161/CIRCRESAHA.117.311588

3. Pham SV, Chilton RJ. EMPA-REG OUTCOME: The Cardiologist's Point of View. Am J Cardiol. 2017 Jul 1;120(1S):S53S58. DOI: 10.1016/j.amjcard.2017.05.011

4. Gupta P, Patel C, Patel H, Narayanaswamy S, Malhotra B, Green JT, Yan GX. T(p-e)/QT ratio as an index of arrhythmogenesis. $\mathrm{J}$ Electrocardiol. 2008 Nov-Dec;41(6):567-74. doi: 10.1016/j.jelectrocard.2008.07.016.

5. Ardahanli I, Celik M. Comparison of Tp-e interval, QTc interval and Tp-e/QTc ratios between non-diabetic and prediabetic population. Ann Med Res 2020;27(12):311722. doi: 10.5455/annalsmedres.2020.09.949

6. Tokatli A, Kiliçaslan F, Alis M, Yiginer O, Uzun M. Prolonged Tp-e Interval, Tp-e/QT Ratio and Tp-e/QTc Ratio in Patients with Type 2 Diabetes Mellitus. Endocrinol Metab (Seoul). 2016 Mar;31(1):105-12. doi: 10.3803/EnM.2016.31.1.105.

7. Akhan O, Ardahanlı İ. Evaluation of Ventricular Polarization in Noncompaction Cardiomyopathy with Electrocardiography in a Different Perspective. ECM 2020;8(4):180185. doi:

10.32596/ejcm.galenos.2020.08.044

8. Braschi A, Frasheri A, Lombardo RM, Abrignani MG, Lo Presti R, Vinci D, Traina M. Association between Tpeak-Tend/QT and major adverse cardiovascular events in patients with Takotsubo syndrome. Acta Cardiol. 2020 Jun 12:1-7. doi: 10.1080/00015385.2020.1776012.

9. Ardahanli I, Akyuz O. The Effect of Hemodialysis Treatment on Ventricular Arrhythmogenesis Parameters in Electrocardiography. Selcuk Med J 2021;10.30733/std.2021.01491 
10. Zelniker TA, Bonaca MP, Furtado RHM, Mosenzon O, Kuder JF, Murphy SA, Bhatt DL, Leiter LA, McGuire DK, Wilding JPH, Budaj A, Kiss RG, Padilla F, Gause-Nilsson I, Langkilde AM, Raz I, Sabatine MS, Wiviott SD. Effect of Dapagliflozin on Atrial Fibrillation in Patients With Type 2 Diabetes Mellitus: Insights From the DECLARE-TIMI 58 Trial. Circulation. 2020 Apr 14;141(15):1227-1234. DOI: 10.1161/CIRCULATIONAHA.119.044183

11. Kors JA, Ritsema van Eck HJ, van Herpen G. The meaning of the Tp-Te interval and its diagnostic value. J Electrocardiol 2008; 41:575-80.

doi: 10.1016/j.jelectrocard.2008.07.030

12. Kusaka H, Koibuchi N, Hasegawa Y, Ogawa H, Kim-Mitsuyama S. Empagliflozin lessened cardiac injury and reduced visceral adipocyte hypertrophy in prediabetic rats with metabolic syndrome. Cardiovasc Diabetol. 2016 Nov 11;15(1):157. DOI: 10.1186/s12933-016-0473-7

13. Hashikata T, Ikutomi M, Jimba T, Shindo A, Kakuda N, Katsushika S, Yokoyama M, Kishi M, Sato T, Matsushita M, Ohnishi S, Yamasaki M. Empagliflozin attenuates neointimal hyperplasia after drug-elutingstent implantation in patients with type 2 diabetes. Heart Vessels 2020; 35(10) :137889. doi:10.1007/s00380-020-01621-0

14. Durak A, Olgar Y, Degirmenci S, Akkus E, Tuncay E, Turan B. A SGLT2 inhibitor dapagliflozin suppresses prolonged ventricular-repolarization through augmentation of mitochondrial function in insulin-resistant metabolic syndrome rats. Cardiovasc Diabetol. 2018 Nov 17;17(1):144. DOI: $10.1186 / \mathrm{s} 12933-018-$ 0790-0 